\title{
STRATEGI MANAJEMEN SDM, ORIENTASI PASAR, DAN KINERJA UKM
}

\author{
Titik Inayati \\ Universitas Wijaya Kusuma Surabaya \\ e-mail: titik.inayati@yahoo.com
}

\begin{abstract}
This study aims to analyze Strategic Human Resource Management (SHRM) and market orientation towards business performance with innovation as an intervening variable for SMEs. This study uses primary and secondary data with descriptive quantitative methods. Analysis using the Anova test. The study population was all leather shoe SMEs in Mojokerto with a sample size of 34 SME shoe products in Mojokerto, East Java Province. Techniques for selecting samples with certain criteria. The results showed that SHRM and market orientation had a significant positive effect on business performance with innovation as an intervening variable. Intervening innovation variables are not the only mediating SHRM relationships and market orientation on business performance, there are other mediating variables.
\end{abstract}

Keywords: strategic human resources management, market oriented, business performance and innovation

\begin{abstract}
ABSTRAK
Penelitian ini bertujuan untuk menganalisis Strategic Human Resource Managemen (SHRM) dan orientasi pasar terhadap kinerja usaha dengan inovasi sebagai variabel intervening pada UKM. Penelitian menggunakan data primer dan sekunder dengan metode kuantitatif deskriptif. Analisis menggunakan uji Anova. Populasi penelitian seluruh UKM sepatu kulit di Mojokerto dengan ukuran sampel 34 UKM produk sepatu di Mojokerto, Provinsi Jawa Timur. Teknik memilih sampel dengan kriteria tertentu. Hasil penelitian menunjukkan bahwa SHRM dan orientasi pasar memiliki pengaruh positif signifikan terhadap kinerja usaha dengan inovasi sebagai variabel intervening. Variabel intervening inovasi bukan satu-satunya pemediasi hubungan SHRM dan orientasi pasar terhadap kinerja usaha, terdapat faktor variabel pemediasi lainnya.
\end{abstract}

Kata kunci: strategic human resource management, orientasi pasar, kinerja usaha dan inovasi

Mojokerto terdiri dari wilayah kota dan kabupaten dengan luas wilayah $734,36 \mathrm{~km}^{2}$. Lokasi wilayah sekitar $50 \mathrm{~km}^{2}$ dari kota provinsi menyebabkan wilayah ini berpotensi berkembang dengan cepat. Apalagi dengan keunikan kota yang memiliki budaya peninggalan Majapahit serta banyak tempat wisata alam lainnya, merupakan daya tarik sendiri bagi wisatawan luar kota untuk berkunjung di Mojokerto. Usaha Kecil dan Menengah (UKM) yang sedang dikembangkan menjadi unggulan Mojokerto saat ini adalah adalah UKM produk sepatu kulit. Permasalahan yang dihadapi UKM saat ini sehingga sulit berkembang adalah terbatasnya kemampuan sumber daya manusia yang mampu 
menentukan kebijakan dan menyusun strategi yang tepat sesuai perkembangan pasar. Peran Strategic Human Resourch Managemen (SHRM) merupakan tren global yang sangat penting dalam menghadapi persaingan untuk menciptakan kinerja usaha yang tinggi (Dessler, 2006). Kualitas SDM sangat penting dan merupakan aset yang tak berwujud (intangible) seperti halnya pengakuan terhadap brand, inovasi, knowladge, maupun kualitas dan kepuasan konsumen.

Kuncoro (2001) menyatakan UKM di Indonesia pada umumnya masih menghadapi beberapa permasalahan diantaranya adalah, (1) lemah dalam memperoleh peluang pasar dan memperluas pangsa pasar, (2) lemah dalam struktur modal dan keterbatasan untuk memperoleh jalur permodalan, (3) lemah dalam organisasi dan manajemen sumber daya manusianya, (4) keterbatasan jaringan usaha kerjasama antar pengusaha, (5) iklim usaha kurang kondusif,dan (6) pembinaan kurang terpadu serta (7) kurangnya kepercayaan serta kepedulian masyarakat. Kondisi ini juga dialami pengusaha produk sepatu Mojokerto. Hal ini menjadi tantangan berat bagi UKM produk sepatu dalam persaingan menghadapi era perdagangan bebas. Pengusaha UKM perlu membuat perencanaan dan strategi yang jitu, agar perusahaan dapat berkembang dengan baik. Pengusaha sepatu perlu memformulasikan SHRM dalam menghadapi tiga tantangan besar, yaitu, (1) upaya dalam meningkatkan kinerja usaha, (2) karyawan harus mempunyai skill dalam membantu mengembangkan perusahaan, dan (3) pemilik usaha harus mampu membuat strategi yang handal bukan hanya menjalankan saja (Dessler, 2006).

Berdasarkan permasalahan dan tantangan yang dihadapi UKM, maka sudah selayaknya berbenah diri dalam menangkap semua peluang yang ada. Jika dilihat dari perspektif perkembangan UKM terhadap permintaan produk dan jasa maka peluang itu sangat besar, tinggal bagaimana memanfaatkan dengan maksimal. Glancey dan Pattigrew (1998) mendefinisikan kinerja dengan merujuk pada tingkat pencapaian atau prestasi perusahan dalam periode tertentu.Tujuan perusahaan pada umumnya untuk memaksimalkan nilai perusahaan yang tercermin dalam perolehan pertumbuhan penjualan, pertumbuhan laba, pertumbuhan modal dan pangsa pasar (Jauch dan Glueck, 1998). Hal yang sama juga diperlukan untuk memaksimalkan nilai usaha UKM produk sepatu Mojokerto.

Perubahan kondisi pasar terkait selera konsumen yang terus berubah diperlukan kecepatan dan kreativitas dalam melakukan inovasi. Thompson (1965)dan Hult (1998) dalam Rofiaty (2012) mendefinisikan inovasi sebagai suatu konsep dalam penerapan gagasan, produk dan proses baru. Hal ini sangat diperlukan dalam meningkatkan kinerja usaha UKM. Beberapa pengusaha produk sepatucenderung tidak berkembang dan kurang inovatif. Salah satu permasalahan yang dihadapi dalam pengembangan UKM produk sepatu adalah adanya kecenderungan cukup puas dengan hasil yang sudah dicapai sehingga tidak melakukan orientasi pasar secara maksimal. Hal ini berdampak pada sulitnya UKM meningkatkan kinerja usahanya. Orientasi pasar merupakan implementasi dari konsep pemasaran. Oleh karena itu orientasi pasar dalam sebuah organisasi dapat diartikan sebagai tindakan organisasi yang konsisten dalam menjalankan konsep pemasaran (Tjiptono, 2004).

Beberapa permasalahan UKM lainnya banyak disebabkan oleh kemampuan Sumber daya manusia (SDM) dalam mengimplementasikan strategi dalam memanfatkan SDM dengan tepat. UKM memerlukan Strategic Human Resource Management (SHRM) dengan konsep lima(5) P, yaitu: (1) Human Resource Philosophy, cara sebuah organisasi dalam memandang sumber daya manusia yang ada dalam organisasi tersebut, (2) Human Resourch Policy, suatu kebijakan yang ditentukan organisasi dalam menjembatani 'nilai' dan keperluan bisnis tertentu, (3) Human Resourch programs, usaha yang dikoordinasi organisasi khususnya ditujukan untuk memulai menyebarkan dan mempertahankan strategi organisasi, (4) Human Resource Practises, merupakan perwujutan pola 
kepemimpinan, manajerial, operasional suatu organisasi, (5) Human Resource Process, bagaimana seluruh aktivitas SDM diidentifikasi, diformulasi dan diimplementasikan dalam sebuah organisasi (Schuler, 1992). SHRM ini berakar dari kemampuan merencanakan tenaga kerja, menegaskan pentingnya manajemen yang efektif dari manusia sebagai sumber keunggulan kompetitif dan menekankan peran strategis dari fungsi SDM (Truss dan Gratton, 1994).

Selain SHRM diperlukan adanya inovasi yang harus dilakukan terus menerus untuk menguasai pasar (Suryana, 2013). Setelah inovasi tersebut berhasil diperkenalkan oleh wirausahawan, pengusaha lain mengikutinya sehingga produk dan teknologi baru tersebut tersebar dalam kehidupan ekonomi. Menurut Levit dan Katryn (1987), inovasi merupakan suatu temuan yang sama sekali belum pernah dikerjakan sebelumnya. Pendapat yang sama menyatakan inovasi sebagai upaya yang dilakukan suatu organisasi untuk mengembangkam produk atau jasa baru, atau kegunaan baru dari produk atau jasa yang ada (Griffin, 2004). Beberapa teori tersebut menunjukkan bahwa inovasi merupakan keterbaruan baik suatu ide, temuan, gagasan yang belum pernah ada sebelumnya.

Perusahaan yang melakukan inovasi juga harus berorientasi pasar agar dalam menjalankan usahanya lebih efektif dan bekerja bersama-sama untuk menyediakan superior customer value (Cravens dan Piercy, 2009). Organisasi tersebut berhasil memindahkan dinding pembatas antara fungsi-fungsi bisnis. Koordinasi antar fungsi menyangkut sumber daya yang dimiliki untuk menciptakan nilai yang superior bagi konsumen. Setiap fungsi dalam organisasi pentingdan mempunyai peran yang unik dalam menciptakan nilai bagi pelanggan. Orientasi pasar merupakan implementasi dari konsep pemasaran. Oleh karena itu orientasi pasar dalam sebuah organisasi dapat diartikan sebagai tindakan organisasi yang konsisten dalam menjalankan konsep pemasaran (Tjiptono, 2004). Organisasi yang berorientasi pada pasar secara terus menerus dalam mencari informasi kepada pelanggan, pesaing dan pasar, memandang informasi ini sebagai persepektif bisnis secara total. Upaya organisasi ini dalam rangka memenuhi kebutuhan dan kepuasan pelanggan.

Kesuksesan dari suatu usaha selayaknya diukur berdasarkan kinerja usaha yang dihasilkan. Alat ukur untuk mengukur kinerja usaha ada beberapa macam, salah satunya adalah rumusan dengan menggunakan balanced scorecard (BSC) dalam rangka mengukur kinerja yang berimbang yaitu aspek keuangan dan non keuangan. BSC dijabarkan menjadi 4 aspek pengukuran, yaitu: (1) aspek pelanggan, (2) aspek proses bisnis internal, (3) aspek pertumbuhan dan pembelajaran, (4) aspek keuangan (Kaplan dan Narton, 1996).

Penelitian sebelumnya pernah dilakukan Muhinder dan Anastasia (2007) meneliti tentang karakteristik khusus hotel yang mempengaruhi kinerja organisasi dan sistem SHRM terhadap kinerja organisasi. Penelitian dilakukanpada hotel yang ada di India. Lin dan Chen (2007) meneliti tentang pelaksanaan inovasi UKM di Taiwan dari integrasi dan persepektif multidimensi serta mengeksplorasi hubungan antara inovasi dengan kinerja. Muathe (2017) meneliti tentang kinerja karyawan di kementrian kesehatan Nairobi city country, karena menilai rendahnya kinerja karyawan sehingga diperlukan praktik SHRM dalam meningkatkan kinerja karyawan.

\section{METODE PENELITIAN}

Populasi dalam penelitian ini adalah seluruh UKM yang ada di Kota dan Kabupaten Mojokerto, yang tidak diketahui jumlahnya. Berdasarkan pertimbangan bahwa jumlah sampel merupakan bagian tertentu yang diambil dari suatu populasi dan diteliti secara rinci (Sugiyono, 2010). Dalam penelitian ini sampel penelitian sebesar 34 UKM dianggap cukup mewakili UKM produk sepatu di Mojokerto. Karakteristik responden sebagai berikut: mempunyai tempat usaha, mempunyai 
ijin usaha, lama usaha minimal lima tahun dan mempunyai tenaga kerja. Metode sampling dilakukan dengan teknik purposive sampling.

Teknik analisis data menggunakan metode statistik untuk menguji masing-masing variabel $\mathrm{X}_{1}, \mathrm{X}_{2}, \mathrm{Z}$, dan $\mathrm{Y}$ yang diperoleh dari hasil kuesioner yang disebarkan pada responden. Metode ini merupakan metode ilmiah untuk mengumpulkan, menyusun, menyajikan serta menganalisis data penelitian yang berwujud angka dengan menggunakan dua program SPSS (Statistical Package For Social Science) versi 24.0 for windows dan WarpPLSversi 6.0 for windows. Program SPSS (Statistical Package For Social Science) ini bertujuan untuk memberikan gambaran data sampel dan menguji kelinieritasan variabel. Program WarpPLS ini sesuai dengan tujuan penelitian yang dilakukan untuk menguji hipotesis tentang hubungan antara dua variabel atau lebih yang membutuhkan suatu metode untuk mengolahnya dengan statistik yang berupa teknik model analisis PLS Regressions.

Penelitian ini menggunakan analisis deskriptif yang terdiri dari minimum, maximum, mean, median, dan standart deviation. Analisis deskriptif ini juga digunakan untuk distribusi karakteristik responden berdasarkan usia antara 17-55 tahun, status pernikahan mulai dari yang sudah menikah atau pernah menikah, pendidikan terakhir minimal SLTA sampai S1 dan lama mempunyai usaha antara 5-25 tahun, mempunyai karyawan 5-20. Analisis deskriptif dihitung menggunakan program SPSS (Statistical Package For Social Science) versi 24.0 for windows untuk memudahkan perhitungan.

Uji hipotesis digunakan untuk menjelaskan arah hubungan antara variabel independen dengan dependen. Pengujian ini dilakukan dengan cara analisis jalur (path analisis) atas model yang dibuat dengan bantuan program WarpPLS versi 6.0 for windowsagar dapat secara stimultan menguji model struktural yang kompleks, sehingga dapat diketahui hasil analisis jalur dalam satu kali analisis regresi.

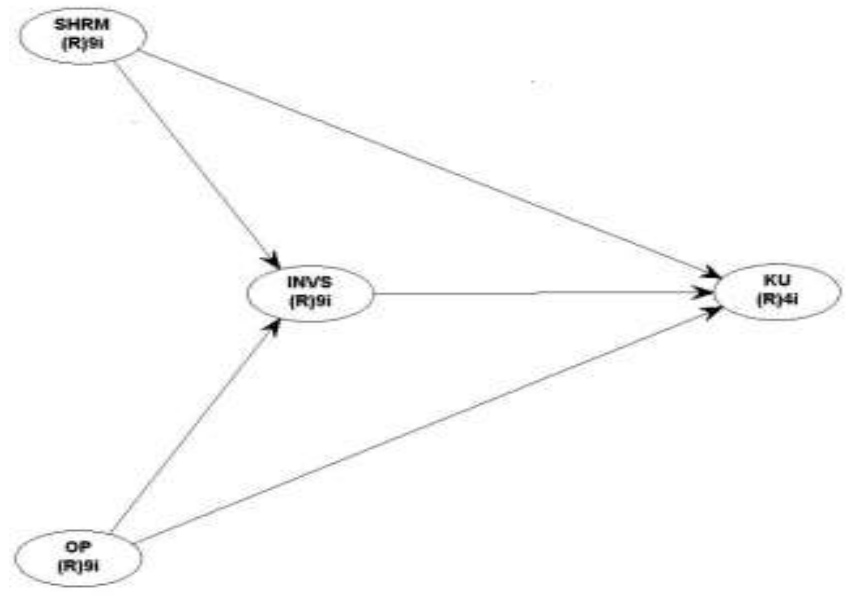

Gambar 1. Model analisis jalur

Hasil korelasi antar konstruk diukur dengan melihat path coefficient dan tingkat signifikansinya yang kemudian dibandingkan dengan hipotesis penelitian. Hipotesis dapat diterima atau ditolak secara statistik dapat dihitung melalui tingkat signifikansinya. Tingkat signifikansi ditentukan sebanyak 10\%, 5\%, dan 1\%. Tingkat signifikansi dalam penelitian ini adalah $10 \%$. Apabila tingkat signifikansi yang dipilih sebesar $10 \%$ maka tingkat signifikansi 0,10 untuk menolak hipotesis. Dalam penelitian ada kemungkinan mengambil keputusan yang salah sebesar $5 \%$ atau 0,05 . Berikut 
dasar pengambilan keputusan yang digunakan yaitu:p-value $\geq 0,05$ maka Ho terima, $p$-value $\leq 0,05$ maka Ho ditolak dan Ha diterima.

\section{UJI Warp PLS BERTAHAP \\ Uji WarpPLS Tahap I (SHRM \& OP $\rightarrow$ KU)}

Gambar 2 merupakan model penelitian dan hasil dari effect size yang telah diperoleh berdasarkan pengolahan data. Gambar ini menjelaskan hubungan Strategic Human Resource Management dan Orientasi Pasarterhadap Kinerja Usaha.

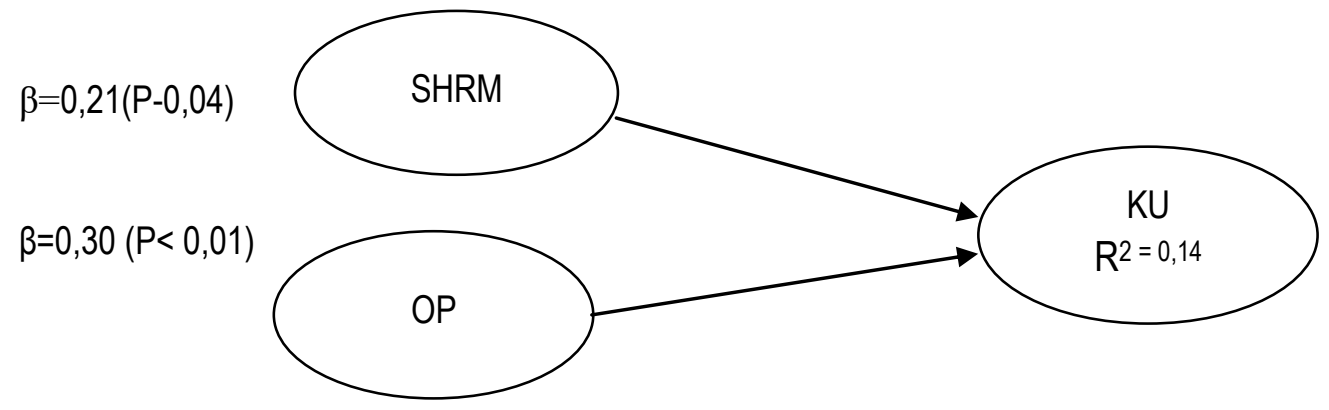

Keterangan:

Gambar 2. Hasil pengujian model Indirect Effects

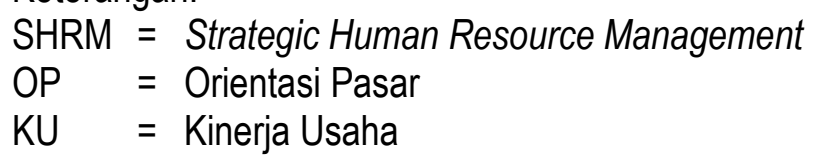

Pada gambar model indirect effect dapat dilihat bahwa variabel Strategic Human Resource Management memiliki pengaruh yang signifikan terhadap kinerja usaha dengan $p$-value 0,04 . Hal ini dapat dilihat dari nilai koefisien jalur yang positif sebesar $\beta=0,21$. Angka ini menunjukkan bahwa jika terjadi peningkatan pada penilaian terhadap Strategic Human Resource Management sebesar satu satuan, maka kinerja usaha akan meningkat sebesar 0,21 .

Variabel orientasi pasarmemiliki pengaruh yang signifikan terhadap kinerja usaha dengan $p$ value $<0,01$. Hal ini dapat dilihat dari nilai koefisien jalur yang positif sebesar $\beta=0,30$. Angka ini menunjukkan bahwa jika terjadi peningkatan pada penilaian terhadap orientasi pasar sebesar satu satuan, maka orientasi pasarakan meningkat sebesar 0,30 . Nilai $R^{2}$ sebesar 0,14 menunjukkan variasi Kinerja Usaha dapat terjelaskan oleh variansi orientasi pasar dan orientasi pasar.

\section{Uji WarpPLS Tahap II Variabel Intervening (SHRM \& OP $\rightarrow$ INVS $\rightarrow$ KU)}

Berikut ini merupakan gambar model penelitian dan hasil dari effect size yang telah diperoleh berdasarkan pengolahan data menggunakan program WarpPLS versi 6.00 for windows. Pada gambar menjelaskan hubungan strategic human resource management dan orientasi pasar terhadap kinerja usaha dengan inovasi sebagai variabel intervening. 


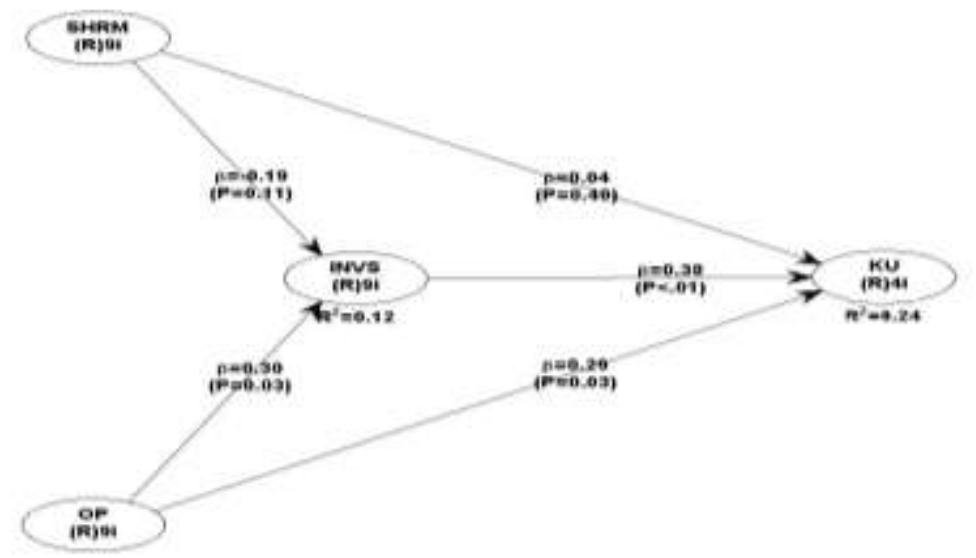

Sumber: Data Primer Diolah (Output WarpPLS 6.0), 2018

Keterangan:

Gambar 3. Hasil Pengujian model Indirect Effects

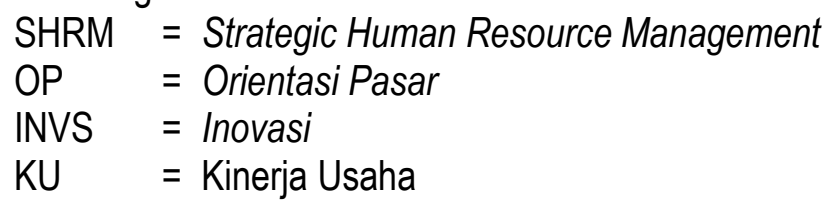

\section{UjiVariance Accounted For (VAF)}

Variance Accounted For (VAF) merupakan ukuran sebesar variabel pemediasi mampu menyerap pengaruh langsung yang sebelumnya signifikan dari model tanpa pemediasi. Jika nilai VAF di atas $80 \%$, maka peran inovasi sebagai pemediasi penuh (full mediation). Jika nilai VAF bernilai di antara $20 \%$ - $80 \%$, maka peran inovasi sebagai pemediasi parsial. Jika nilai VAF bernilai kurang dari 20\%, maka peran inovasi disimpulkan tidak ada efek mediasi (Hair dkk, 2013) (dalam Sholihin dan Ratmono, 2013). Berikut tabel perhitungan VAF:

Tabel 1. Perhitungan Variance Accounted For (VAF)

\begin{tabular}{|c|c|}
\hline $\begin{array}{l}\text { Pengaruh Tidak Langsung } \\
\text { 1. Strategic Human Resource Management } \rightarrow \text { Inovasi } \rightarrow \text { Kinerja Usaha } 0,19 \times 0,38 \\
\text { 2. Orientasi Pasar } \rightarrow \text { Inovasi } \rightarrow \text { Kinerja Usaha } \\
0,30 \times 0,38\end{array}$ & 0,072 \\
\hline Pengaruh Langsung & \\
\hline 1. Strategic Human Resource Management $\rightarrow$ Kinerja Usaha & 0,04 \\
\hline Orientasi Pasar $\rightarrow$ Kinerja Usaha & 0,29 \\
\hline 3. Inovasi $\rightarrow$ Kinerja Usaha & 0,38 \\
\hline Pengaruh Total = & \\
\hline $\begin{array}{l}\text { 1. Strategic human resource management, Inovasi, dan Kinerja usaha } \\
0,072+0,04\end{array}$ & 0,112 \\
\hline $\begin{array}{l}\text { 2. Orientasi pasar, Inovasi, dan Kinerja usaha } \\
0,114+0,29\end{array}$ & 0,404 \\
\hline VAF = Pengaruh Tidak Langsung / Pengaruh Total & \\
\hline $\begin{array}{l}\text { 1. VAF Strategic human resource management }=0,072 / 0,112 \\
\text { 2. VAF Orientasi pasar }=0,114 / 0,404\end{array}$ & $\begin{array}{l}0,65 \\
0,28\end{array}$ \\
\hline
\end{tabular}

Sumber : Data Primer Diolah (Output WarpPLS 6.0), 2018 
Berdasarkan perhitungan VAF, untuk menguji pengaruh variabel inovasi sebagai pemediasi antara pengaruh strategic human resource management terhadap kinerja usaha adalah sebesar 0,65 atau 65\%. Dari hasil tersebut dapat disimpulkan bahwa inovasi memiliki efek mediasi parsial (Hair $d k k, 2013$ dalam Sholihin dan Ratmono, 2013). Efek mediasi parsial ini mengindikasikan bahwa inovasi bukan satu-satunya yang dapat menjadi variabel intervening pada model ini tetapi ada variabel intervening lainnya yang tidak diteliti dalam penelitian ini. Pada tabel tersebut juga menunjukkan nilai VAF untuk variabel inovasi sebagai pemediasi antara pengaruh orientasi pasar terhadap kinerja usaha sebesar 0,28 atau $28 \%$. Berdasarkan nilai VAF tersebut dapat disimpulkan bahwa inovasi merupakan pemediasi parsial sehingga terdapat variabel intervening lain yang dapat menjadi variabel intervening untuk model lain yang tidak diteliti dalam penelitian ini.

\section{HASIL DAN PEMBAHASAN}

\section{Hasil Pengujian Hipotesis Pertama}

Hipotesis pertama dalam penelitian ini adalah strategic human resource management berpengaruh signifikan terhadap inovasi. Ringkasan hasil analisis WarpPLS yang diolah dengan menggunakan progam WarpPLS 6.0 for windows dalam penelitian ini dapat dilihat pada Tabel 2.

Tabel 2. Hasil Pengujian Hipotesis Kesatu

\begin{tabular}{lcccccc}
\hline \multicolumn{1}{c}{ Variabel } & $\begin{array}{c}\text { Koefisien } \\
\text { Jalur }(\beta)\end{array}$ & $\begin{array}{c}p- \\
\text { value }\end{array}$ & $\begin{array}{c}\text { Effect } \\
\text { Size }\end{array}$ & Kriteria & Hasil & Keterangan \\
\hline $\begin{array}{l}\text { Strategic human } \\
\text { resource } \\
\begin{array}{l}\text { management } \\
\text { terhadap Inovasi }\end{array}\end{array}$ & 0,19 & 0,011 & 0,142 & $p<0,05$ & Signifikan & Diterima \\
\hline
\end{tabular}

Sumber: Data Primer Diolah (WarpPLS 6.0), 2017

Berdasarkan Tabel 2, diketahui bahwa strategic human resource management berpengaruh signifikan terhadap inovasi dengan nilai $\beta$ positif sebesar 0,19 dengan $p$-value sebesar 0,011. Kontribusi strategic human resource management untuk menjelaskan inovasi dapat dilihat dari nilai effect size sebesar 0,142. Maka dapat disimpulkan bahwa strategic human resource management memiliki pengaruh signifikan terhadap inovasi pada karyawan UKM sepatu dan alas kaki kota Mojokerto, sehingga dapat dinyatakan bahwa hipotesis pertama diterima.

Strategic humas resource management menunjukkan berpengaruh positif dan signifikan terhadap inovasi pada hipotesis pertama dapat diterima dengan koefisien jalur yang positif $\beta=0,19$ yang menunjukan semakin tinggi Strategic humas resource management maka semakin tinggi inovasi pula. Begitupun sebaliknya semakin rendah strategic humas resource management maka inovasi juga semakin rendah. Kontribusi strategic humas resource management untuk menjelaskan inovasi dapat dilihat dari nilai effect size sebesar 0,142 berarti variabel Strategic humas resource managementmempengaruhi inovasi sebesar $14,2 \%$ dan sisanya dipengaruhi variabel lain.

\section{Hasil Pengujian Hipotesis kedua}

Hipotesis kedua dalam penelitian ini adalah orientasi pasar berpengaruh signifikan terhadap inovasi. Ringkasan hasil analisis WarpPLS yang diolah dengan menggunakan progam WarpPLS 6.0 for windows dalam penelitian ini dapat dilihat pada Tabel 3 . 
Tabel 3. Hasil Pengujian Hipotesis Kedua

\begin{tabular}{ccccccc}
\hline Variabel & $\begin{array}{c}\text { Koefisien } \\
\text { Jalur }(\beta)\end{array}$ & $\begin{array}{c}p- \\
\text { value }\end{array}$ & $\begin{array}{c}\text { Effect } \\
\text { Size }\end{array}$ & Kriteria & Hasil & Keterangan \\
\hline $\begin{array}{l}\text { Orientasi pasar } \\
\text { terhadap Inovasi }\end{array}$ & 0,30 & 0,03 & 0,174 & $p<0,05$ & Signifikan & Diterima \\
\hline
\end{tabular}

Sumber: Data Primer Diolah (WarpPLS 6.0), 2017

Berdasarkan Tabel 3, diketahui bahwa pengaruh orientasi pasar berpengaruh signifikan terhadap inovasi dengan nilai $\beta$ positif sebesar 0,30 dengan $p$-value sebesar 0,03 . Kontribusi pengaruh orientasi pasar untuk menjelaskan inovasi dapat dilihat dari nilai effect size, effect size nilai sebesar 0,174 . Maka dapat disimpulkan bahwa pengaruh orientasi pasar memiliki pengaruh signifikan terhadap inovasi pada karyawan UKM sepatu dan alas kaki kota Mojokerto, sehingga dapat dinyatakan bahwa hipotesis kedua diterima.

Orientasi pasar menunjukkan berpengaruh positif dan signifikan terhadap inovasi pada hipotesis kedua dapat diterima dengan nilai koefisien jalur yang positif $\beta=0,30 p$-value sebesar 0,03 yang menunjukkan bahwa kenaikan atau penurunan yang terjadi pada variabel orientasi pasar berpengaruh searah terhadap variabel inovasi. Kondisi orientasi pasar berkaitan dengan respons dari inovasi Ketika UKM berada pada situasi orientasi pasar yang tinggi, maka respons karyawan cenderung tinggi begitupula sebaliknya jika orientasi pasar yang rendah, maka karyawan cenderung rendah. Bisa dikatakan bahwa orientasi pasar merupakan prediktor bagi inovasi. Kontribusi orientasi pasar untuk menjelaskan inovasi dapat dilihat dari effect size sebesar 0,174 berarti variabel orientasi pasar mempengaruhi inovasi sebesar $17,4 \%$ dan sisanya dipengaruhi variabel lain.

\section{Hasil Pengujian Hipotesis Ketiga}

Hipotesis ketiga dalam penelitian ini adalah inovasi berpengaruh signifikan terhadap kinerja usaha. Ringkasan hasil analisis WarpPLS yang diolah dengan menggunakan progam WarpPLS 6.0 for windows dalam penelitian ini dapat dilihat pada Tabel 4.

Tabel 4. Hasil Pengujian Hipotesis Ketiga

\begin{tabular}{lcccccc}
\hline \multicolumn{1}{c}{ Variabel } & $\begin{array}{c}\text { Koefisien } \\
\text { Jalur }(\beta)\end{array}$ & $\begin{array}{c}\mathrm{p}- \\
\text { value }\end{array}$ & $\begin{array}{c}\text { Effect } \\
\text { Size }\end{array}$ & Kriteria & Hasil & Keterangan \\
\hline $\begin{array}{l}\text { Inovasi terhadap } \\
\text { Kinerja usaha }\end{array}$ & 0,38 & 0,01 & 0,109 & $\mathrm{P}<0,05$ & Signifikan & Diterima \\
\hline Sumber : Data Primer Diolah (WarpPLS 6.0), 2017 & & & &
\end{tabular}

Berdasarkan Tabel 4, diketahui bahwa pengaruh inovasi berpengaruh signifikan terhadap kinerja usaha dengan nilai $\beta$ positif sebesar 0,38 dengan $p$-value sebesar 0,01 . Kontribusi pengaruh inovasi untuk menjelaskan kinerja usaha dapat dilihat dari nilai effect size sebesar 0,109 dan merupakan pemberi pengaruh terbesar terhadap kinerja usaha dibanding variabel strategic human resource management dan orientasi pasar. Maka dapat disimpulkan bahwa pengaruh inovasi memiliki pengaruh signifikan terhadap kinerja usaha pada karyawan UKM sepatu dan alas kaki kota Mojokerto, sehingga dapat dinyatakan bahwa hipotesis ketiga diterima.

Inovasi disimpulkan memiliki pengaruh positif dan signifikan terhadap Kinerja usaha pada hipotesis ketiga dapat diterima dengan nilai koefisien jalur yang positif $\beta=0,38$ yang menunjukan semakin tinggi inovasi maka semakin tinggi kinerja usaha. Begitupun sebaliknya semakin rendah 
inovasi maka Kinerja usaha juga semakin rendah. Kontribusi inovasi untuk menjelaskan Kinerja usahadapat dilihat dari effect size sebesar 0,109 berarti variabel inovasi mempengaruhi kinerja usaha sebesar $10,9 \%$ dan sisanya dipengaruhi variabel lain. Inovasi merupakan pemberi pengaruh terbesar terhadap kinerja usaha dibanding variabel Strategic humas resource managementdan orientasi pasar.

\section{Hasil Pengujian Hipotesis Keempat}

Hipotesis keempat dalam penelitian ini adalah strategic human resource management berpengaruh signifikan terhadap kinerja usaha. Ringkasan hasil analisis WarpPLS yang diolah dengan menggunakan progam WarpPLS 6.0 for windows dalam penelitian ini dapat dilihat pada Tabel 5 .

Tabel 5. Hasil Pengujian Hipotesis keempat

\begin{tabular}{|c|c|c|c|c|c|c|}
\hline Variabel & $\begin{array}{c}\text { Koefisien } \\
\text { Jalur ( } \beta \text { ) }\end{array}$ & $\begin{array}{c}\mathrm{p}- \\
\text { value }\end{array}$ & $\begin{array}{l}\text { Effect } \\
\text { Size }\end{array}$ & Kriteria & Hasil & Keterangan \\
\hline $\begin{array}{l}\text { Strategic human } \\
\text { resource management } \\
\text { terhadan Kineria unaha }\end{array}$ & 0,04 & 0,48 & 0,036 & $p<0,05$ & $\begin{array}{c}\text { Tidak } \\
\text { Signifikan }\end{array}$ & Ditolak \\
\hline
\end{tabular}

Sumber : Data Primer Diolah (WarpPLS 6.0), 2017

Berdasarkan Tabel 5, diketahui bahwa pengaruh strategic human resource management berpengaruh signifikan terhadap kinerja usaha dengan nilai $\beta$ positif sebesar 0,04 dengan $p$-value sebesar 0,48. Kontribusi pengaruh strategic human resource management untuk menjelaskan kinerja usaha dapat dilihat dari nilai effect size sebesar 0,036 . Maka dapat disimpulkan bahwa pengaruh strategic human resource management memiliki pengaruh tidak signifikan terhadap kinerja usaha pada karyawan UKM sepatu dan alas kaki kota Mojokerto, sehingga dapat dinyatakan bahwa hipotesis keempat ditolak.

Strategic humas resource management menunjukkan memiliki pengaruh positif dan tidak signifikan terhadap komitemen organisasi pada hipotesis ke empat dapat diterima. Kontribusi Strategic humas resource management untuk menjelaskan Kinerja usaha dapat dilihat dari effect size sebesar 0,036 berarti variabel strategic humas resource management mempengaruhi Kinerja usaha sebesar $3,6 \%$ dengan pengaruh yang lemah dan sisanya dipengaruhi variabel lain.

\section{Hasil Pengujian Hipotesis Kelima}

Hipotesis kelima dalam penelitian ini adalah orientasi pasar berpengaruh signifikan terhadap kinerja usaha. Ringkasan hasil analisis WarpPLS yang diolah dengan menggunakan progam WarpPLS 6.0 for windows dalam penelitian ini dapat dilihat pada Tabel 6 .

Tabel 6. Hasil Pengujian Hipotesis Kelima

\begin{tabular}{lcccccc}
\hline \multicolumn{1}{c}{ Variabel } & $\begin{array}{c}\text { Koefisien } \\
\text { Jalur }(\beta)\end{array}$ & $\begin{array}{c}\mathrm{p}- \\
\text { value }\end{array}$ & $\begin{array}{c}\text { Effect } \\
\text { Size }\end{array}$ & Kriteria & Hasil & Keterangan \\
\hline $\begin{array}{l}\text { Orientasi pasar } \\
\text { terhadap Kinerja }\end{array}$ & 0,29 & 0,03 & 0,045 & $\mathrm{P}<0,05$ & Signifikan & Diterima \\
usaha
\end{tabular}


Berdasarkan Tabel 6, diketahui bahwa pengaruh orientasi pasar berpengaruh positif dan signifikan terhadap kinerja usaha dengan nilai $\beta$ positif sebesar 0,29 dengan $p$-value sebesar 0,03. Kontribusi pengaruh orientasi pasar untuk menjelaskan kinerja usaha dapat dilihat dari nilai effect siz sebesar 0,045. Maka dapat disimpulkan bahwa pengaruh orientasi pasar memiliki pengaruh signifikan terhadap kinerja usaha pada karyawan UKM sepatu dan alas kaki kota Mojokerto, sehingga dapat dinyatakan bahwa hipotesis kelima diterima.

Orientasi pasar disimpulkan memiliki pengaruh positif dan signifikan terhadap Kinerja usaha pada hipotesis kelima dapat diterima. Kontribusi orientasi pasar untuk menjelaskan kinerja usaha dapat dilihat dari effect size sebesar 0,045 berarti variabel orientasi pasar mempengaruhi Kinerja usaha sebesar $4,5 \%$ dengan pengaruh yang lemah dan sisanya dipengaruhi variabel lain.

\section{Hasil Pengujian Hipotesis keenam}

Pada hipotesis keenam dalam penelitian ini adalah strategic human resource management dan orientasi pasar berpengaruh secara signifikan terhadap kinerja usaha dengan inovasi sebagai variabel intervening. Ringkasan hasil analisis intervening perbandingan model dalam penelitian ini dapat dilihat pada Tabel 7.

Tabel 7. Hasil Pengujian Hipotesis Keenam Berdasarkan Perbandingan Model

\begin{tabular}{|c|c|c|c|}
\hline & $\begin{array}{c}\text { Perbandingan Model } \\
\text { Indirect effect } \\
\text { Tahap } 1 \text { dan } 2 \\
\end{array}$ & Kriteria & Hasil \\
\hline Strategic & & - $\quad$ nilai tetap signifikan dan & \\
\hline human resource & 0,21 turun menjadi & tidak berubah $=$ mediasi & \\
\hline $\begin{array}{c}\text { management } \\
\rightarrow \text { Kinerja } \\
\text { usaha }\end{array}$ & 0,04 & $\begin{array}{l}\text { tidak didukung } \\
\text { - } \quad \text { nilai turun tetapi tetap } \\
\text { signifikan = partial }\end{array}$ & $\begin{array}{c}\text { partial } \\
\text { mediation }\end{array}$ \\
\hline $\begin{array}{c}\text { Orientasi } \\
\text { pasar } \rightarrow \text { Kinerja } \\
\text { usaha }\end{array}$ & $\begin{array}{c}0,30 \text { turun menjadi } \\
0,29\end{array}$ & $\begin{array}{l}\text { mediation } \\
\text { - } \quad \text { nilai turun dan menjadi } \\
\text { tidak signifikan = mediasi } \\
\text { penuh (full mediation). }\end{array}$ & $\begin{array}{c}\text { partial } \\
\text { mediation }\end{array}$ \\
\hline
\end{tabular}

Berdasarkan Tabel 7 dapat diketahui bahwa bentuk partial mediation atau dengan kata lain inovasi memediasi secara parsial pengaruh strategic human resource management terhadap kinerja usaha dan orientasi pasar terhadap kinerja usaha. Bentuk partial mediation ini menunjukkan bahwa inovasi bukan satu-satunya pemediasi hubungan strategic human resource management dan orientasi pasar terhadap kinerja usaha namum terdapat faktor pemediasi lain. Hasil pengujian menunjukkan dukungan terhadap hipotesis bahwa strategic human resource management dan orientasi pasar berpengaruh tidak langsung terhadap kinerja usaha dengan inovasi sebagai pemediasi parsial.Ringkasan hasil analisis intervening perbandingan model dalam penelitian ini dapat dilihat pada Tabel 8. 
Tabel 8. Hasil Pengujian Hipotesis Keenam Berdasarkan VAF

\begin{tabular}{|c|c|c|c|c|}
\hline & VAF & Kriteria & Hasil & Keterangan \\
\hline $\begin{array}{l}\text { Strategic } \\
\text { humas } \\
\text { resource } \\
\text { managem } \\
\text { ent }\end{array}$ & 0,65 & $\begin{array}{l}\text { - } \quad \text { Nilai VAF di atas } 80 \% \text {, maka } \\
\text { pemediasi penuh (full mediation). } \\
\text { - } \quad \text { Nilai VAF di antara } 20 \% \text { - } 80 \% \text {, } \\
\text { maka pemediasi parsial. } \\
\text { - Nilai VAF < } 20 \% \text {, maka tidak ada }\end{array}$ & $\begin{array}{c}\text { partial } \\
\text { mediation }\end{array}$ & Diterima \\
\hline $\begin{array}{c}\text { Orientasi } \\
\text { pasar }\end{array}$ & 0,28 & efek mediasi & $\begin{array}{l}\text { partial } \\
\text { mediation }\end{array}$ & Diterima \\
\hline
\end{tabular}

Berdasarkan Tabel 8 perhitungan VAF untuk uji pengaruh variabel inovasi sebagai pemediasi parsial antara pengaruh strategic humas resource management terhadap kinerja usaha adalah sebesar 0,65 atau 65\%, dan antara Orientasi pasar terhadap Kinerja usaha sebesar 0,28 atau $28 \%$ sehingga dapat dinyatakan bahwa hipotesis keenam diterima.

Hasil dugaan yang didukung dengan kenyataan bahwa strategic humas resource management dan orientasi pasar memiliki pengaruh signifikan terhadap inovasi serta inovasi yang memiliki pengaruh signifikan terhadap kinerja usaha. Secara keseluruhan, dapat dilihat bahwa hipotesis keenam yang menyatakan strategic humas resource management dan orientasi pasar memiliki pengaruh signifikan terhadap Kinerja usaha dengan inovasi sebagai variabel intervening dapat diterima.

Strategic humas resource management dan orientasi pasar memiliki pengaruh yang positif dan signifikan terhadap Kinerja usaha dengan inovasi sebagai variabel intervening. Berdasarkan uji perbandingan model indirect effect tahap 1 dan 2 variabel intervening yaitu inovasi berbentuk partial mediation atau bukan satu-satunya pemediasi hubungan strategic humas resource managementdan orientasi pasar terhadap Kinerja usaha namum terdapat faktor pemediasi lain. Pada perhitungan VAF, pengaruh variabel inovasi sebagai pemediasi antara pengaruh strategic humas resource management terhadap kinerja usaha adalah sebesar 0,65 atau $65 \%$. Dari hasil tersebut dapat disimpulkan bahwa inovasi memiliki efek mediasi parsial. Sedangkan variabel inovasi sebagai pemediasi antara pengaruh orientasi pasar terhadap Kinerja usaha sebesar 0,28 atau 28\%.

Dengan demikian kinerja usaha sangat penting dan membawa dampak yang besar bagi organisasi ataupun perusahaan. Karena dengan adanya Kinerja usaha akan membuat karyawan lebih mencurahkan semua kemampuannya untuk memberikan kontribusi terbaik bagi perusahaan. Dengan demikian, karyawan yang berkinerja baik kepada perusahaan akan memberikan suatu keunggulan tambahan dan berusaha dengan segala upaya bagi perusahaan agar semakin maju, tetap eksis dalam ketatnya persaingan antar perusahaan dan tercapainya tujuan perusahaan.

\section{SIMPULAN}

Berdasarkan hasil analisis dan pembahasan maka dapat disimpulkan sebagai berikut pada UKM sepatu kulit di Mojokerto:(1) strategic human resource management memiliki pengaruh yang positif dan signifikan terhadap inovasi, (2) orientasi pasar memiliki pengaruh yang positif dan signifikan inovasi, (3) inovasi memiliki pengaruh yang positif dan signifikan terhadap kinerja usaha, (4) strategic human resource management memiliki pengaruh yang positif dan tidak signifikan terhadap kinerja usaha, (5) orientasi pasar memiliki pengaruh yang positif dansignifikan terhadap 
kinerja usaha,dan (6) strategic human resource management danorientasi pasar memiliki pengaruh yang positif dan signifikan terhadap kinerja usaha dengan inovasi sebagai variabel intervening. Variabel intervening inovasi berbentuk partial mediation atau bukan satu-satunya pemediasi hubungan strategic human resource management dan orientasi pasar terhadap kinerja usaha namum terdapat faktor pemediasi lain.

\section{REFERENSI}

Cravens, David W. \& Nigel F. Piercy. (2009). Strategic Marketing. 7th Edition, New York:McGraw-Hill. Dessler, Gary. (2006). Manajemen Sumber Daya Manusia. Jilid II. Jakarta PT. Indeks.

Fandy Tjiptono. (2007). Strategi Pemasaran. Edisi kedua.Penerbit Andi, Yogyakarta.

Glancey, Greig \& Pattigrew. (1998). Entrepreneurial Dynamics in Small Business Service Firms.

International Journal of Entrepreneurial Behavior \& Research, Vol 4 (3), 1998. 249-268.

Griffin. (2004). Komitmen organisasi. Terjemahan. Jakarta. Erlangga.

Jauch, Lawrence, R \& Glueck, William. (1998). Manajemen Strategis dan Kebijakan Perusahaan. Terjemahan Murad dan Henry Sitanggung. Penerbit Erlangga. Jakarta.

Kaplan, Robert S \& David P.Narton. (1996). Focusing Your Organization OnStrategy-With The Balance Scorecard.2nd Edition. Harvard Business Review. 2000.

Kuncoro, Mudrajat. (2001). Metode Kuantitatif: Teori dan Aplikasi untuk Bisnis dan Ekonomi. Yogyakarta: UPP-AMP YKPN.

Levit \& Katryn. M. (1987). National Culture and Teaching Culture. American Anthropological Association. University of Michigan Dearborn.

Lin, Carol Yeh-Yun \& Mavis Yi-Ching Chen. (2007). Does Innovation Lead to Performance? Management Research News, 30 (2): 115-132.

Mathis, L. Robert., Jakson, \& H. John. (2001). Human Resource Management. Jakarta. Salemba. Muathe, Stephen. (2017). Employed Engagement, Organisation Comitment and performance of Selected Statae Corporation in Kenya. European Scientific Journal, Vol. 13. Issu 33.

Muhinder, C. \& AK. Anastasia. (2007). The impact of HRM practices on organisational performance in the Indian hotel industry. Employee Relations Journal, 29 (6). 576-594.

Rofiaty. (2012). Inovasi dan Kinerja. Malang. Universitas Brawijaya Press.

Schuler. R.S. \& Walker, J.W. (1992). Human Resource Strategy: Focusing on Issues and Actions. Organizational Dynamics, New York: West Publishing Company.

Sholihin, Mahfud \& Ratmono, Dwi. (2013). Analisis SEM-PLS dengan WrapPLS 3.0 Untuk Hubungan Nonlinear dalam Penelitian Sosial dan Bisnis. Yogyakarta: Penerbit ANDI.

Sugiyono. (2010). Metode Penelitian Kuantitatif dan Kualitatif. Bandung: Alfabeta.

Suryana. (2013). Kewirausahaan Kiat dan Proses Menuju Sukses. Jakarta: Salemba Empat.

Tjiptono. (2004). Strategi Pemasaran, edisi kedua, Yogyakarta: Andi.

Truss,C \& Gratton, L. (1994). Strategic Human Resource Management: A conceptual Approach. The Internasional Journal of Human resource Management, Volume 5 Issue 3. No.663. 